\title{
TANGGUNG JAWAB NEGARA DAN MEKANISME PENYELESAIAN EXTRAJUDICIAL KILLINGS 1965
}

\author{
Mardiyono \\ Alumni Magister Ilmu Hukum UKSW serta Pegiat HAM 1965 \\ Korespondensi: gusmardi2002@yahoo.com
}

\begin{abstract}
Abstrak
Persoalan extrajudicial killings 1965 merupakan kejahatan terhadap kemanusiaan dan termasuk kejahatan HAM berat sesuai Pasal 7 UU No. 26 Tahun 2000. Penghukuman yang dilakukan tanpa proses pengadilan merupakan pengkhianatan terhadap nilai-nilai kemanusiaan yang terkandung dalam Pasal 1 ayat (3) Undang-Undang Dasar 1945. Dalam Masstricht Guidelines on Violations of Economic, Social and Cultural Rights, negara berkewajiban melindungi hak-hak sipil dan politik, hak-hak ekonomi, sosial dan budaya, dengan memberlakukan tiga jenis kewajiban pada Negara, yaitu: kewajiban untuk menghormati, melindungi dan memenuhi. Kegagalan untuk melakukan salah satu dari tiga kewajiban tersebut merupakan pelanggaran hak yang dilakukan oleh negara. Terkait dengan extrajudicial killings 1965, negara dapat memikul kewajiban baik sebagai akibat dari perbuatannya sendiri (acts of commision) maupun oleh karena pembiaran (acts of ommission).
\end{abstract}

Kata-kata Kunci: Extrajudicial Killings; Tanggung Jawab Negara.

\begin{abstract}
The infamous tragedy of extrajudicial killings in Indonesia in 1965 could be categorized as crimes against humanity, as well as a serious violation of human rigts as set forth in Article 7 of Law No. 26, 2000 and Article 1 Paragraph (3) of the Constitution of 1945. In the Maastricht Guidelines on Violations of Economic, Social and Cultural Rights, the state is obliged to protect the civil, political and economic rights, as well as social and cultural rights. to impose state obligations (the obligation to respect, protect and fulfill). Failure to do any of these constitutes a violation of rights by the state. In relation to extrajudicial killings that took place in 1965, the state may assume obligations both as a result of his own actions (acts of commission) as well as because of its omission.
\end{abstract}

Key Words: Extrajudicial Killings; State Responsibility. 


\section{PENDAHULUAN}

Krisis politik pasca Gestapu (Gerakan 30 September 1965) oleh Pemerintah Orde Baru disingkat G30S/PKI. ${ }^{1}$ Penyebutan G30S/PKI oleh Orde Baru sebagai justifikasi bahwa tragedi politik 1965 yang mengakibatkan terbunuhnya 6 jenderal di daerah Halim Perdanakusuma didalangi oleh Partai Komunis Indonesia (PKI). Tragedi kemanusiaan pasca 1965 menurut Aswi Warman Adam, memunculkan epilog gerakan 30 September serta serangkaian peristiwa: (1) peristiwa satu malam pada tanggal 30 September 1965; (2) penangkapan, penahanan, perburuan, pembunuhan massal yang memakan korban minimal setengah juta jiwa 1965-1966; (3) pencabutan paspor mahasiswa Indonesia di luar negeri sehingga mereka menjadi orang terbuang atau manusia eksil, (4) pembuangan paksa lebih dari 10.000 orang ke Pulau Buru (1960-1979); (5) stigma dan diskriminasi terhadap jutaan keluarga korban $1965 .^{2}$

Senada dengan Asvi, diungkapkan oleh Baskoro T. Wardaya, bahwa pasca peristiwa 30 September 1965, ditandai dengan dimunculkannya histeria antikomunis berupa penangkapan, penyiksaan, pembunuhan serta pembuangan jutaan orang yang dituduh berideologi kiri. ${ }^{3}$ John Rosa bahkan mensinyalir bahwa Suharto dengan rezim "Orde Baru" menuduh Partai Komunis Indonesia (PKI) mendalangi G-30-S, dan selanjutnya menyusun rencana pembasmian terhadap orang-orang yang terkait dengan partai itu. ${ }^{4}$

Tindakan pembantaian terhadap orang-orang PKI tahun 1965 tanpa proses pengadilan oleh penulis dimaknai sebagai extrajudicial killings 1965. Tindakan extrajudicial killings 1965 merupakan tindakan yang bertentangan dengan konstitusi negara Indonesia serta merupakan pengkhianatan terhadap nilai-nilai kemanusiaan yang terkandung dalam Pasal 1 ayat (3) Undang-Undang Dasar 1945.

Dalam konteks lain, extrajudicial killings 1965 menurut Maastricht Guidelines on Violations of Economic, Social and Cultural Rights, negara berkewajiban melindungi hak-hak sipil dan politik, hak-hak ekonomi, sosial dan budaya, dengan memberlakukan tiga jenis kewajiban pada Negara, yaitu: kewajiban untuk menghormati, melindungi dan memenuhi. Kegagalan untuk melakukan salah satu dari tiga kewajiban tersebut merupakan pelanggaran hak yang dilakukan oleh negara. Oleh karena itu, extrajudicial killings 1965 tidak dapat dikesampingkan atau dibiarkan berhenti begitu saja. Apalagi kejahatan-kejahatan tersebut tidak

\footnotetext{
$1 \quad$ Hermawan Sulistyo, Palu Arit di Ladang Tebu: Sejarah Pembantaian Massal yang Terlupakan (Jombang-Kediri 1965-1966) (Kepustakaan Populer Gramedia 2011) 2.

2 Asvi Marwan Adam, Melawan Lupa: Menepis Stigma setelah Prahara 1965 (PT. Kompas Media Nusantara 2015) viii.

3 Baskara T. Wardaya, ed., Luka Bangsa Luka Kita; Pelanggaran HAM Masa Lalu dan Tawaran Rekonsiliasi (Galang Press 2014) 61.

$4 \quad$ John Rosa, Dalih Pembunuhan Massal: Kudeta 30 September dan Kudeta Suharto (Institut Sejarah Sosial Indonesia dan Hasta Mitra 2008) 5.
} 
mengenal daluarsa (non-statutory limiitation), sehingga tidak ada batas waktu dalam penyelesaiannya sebagaimana dikukuhkan oleh Pasal 46 UU No. 26 Tahun 2000 tentang Pengadilan Hak Asasi Manusia. ${ }^{5}$

Peristiwa tersebut menuntut adanya tanggung jawab negara dalam upaya untuk mengungkap tabir gelap tentang kebenaran sejarah, disamping upaya mewujudkan rasa keadilan bagi korban maupun keluarga korban. Contoh tangung jawab negara pernah dilakukan pada kasus relokasi dan internment penduduk sipil warga AS (Amerika Serikat) keturunan Jepang. Hampir 120.000 orang Jepang-Amerika diinternir (dipaksa pindah dan dibatasi) oleh militer AS menyusul serangan Jepang di Pearl Harbor 1941. Melalui the Civil Liberties Act 10 Agustus 1988, pemerintah AS menyatakan permintaan maaf atas pelanggaran HAM masa lalu terhadap warga negara AS keturunan Jepang dan sekaligus mengakui hak mereka untuk mengajukan gugatan. ${ }^{6}$

Dalam hukum kebiasaan internasional sebuah negara dianggap me- lakukan pelanggaran berat HAM (gross violation of human rights) jika: (1) negara tidak berupaya melindungi atau justru meniadakan hak-hak warganya yang digolongkan sebagai non-derogable rights; ${ }^{7}$ atau (2) negara yang bersangkutan membiarkan terjadinya atau justru melakukan melalui aparat-aparatnya tindak kejahatan internasional (international crimes) atau kejahatan serius (serious crimes) yaitu kejahatan genosida, kejahatan terhadap kemanusiaan dan kejahatan perang. ${ }^{8}$ Oleh karena itu sebagai bentuk tanggungjawab terhadap kewajibannya, negara harus melakukan penyelesaian extrajudicial killing 1965, baik dengan mekanisme yudisial maupun mekanisme non yudisial. Hal itu akan menjadi fokus pembahasan artikel ini.

\section{PEMBAHASAN}

\section{Tangung Jawab Negara dalam Extrajudicial Killings 1965}

Pentingnya penyelesaian extrajudicial killings 1965 adalah untuk menegakkan keadilan sebagaimana dituntut

Andrey Sujatmoko, Hukum HAM dan Hukum Humaniter (Rajawali Press 2015) 68.

Titon Slamet Kurnia, Reparasi (Reparation) terhadap Korban Pelanggaran HAM di Indonesia (PT. Citra Aditya Bakti 2005) 273.

$7 \quad$ Article 4 ICCPR menentukan sejumlah hak yang bersifat non-derogable sebagai berikut: Right to life (Art. 6); Prohibition of torture, cruel, inhuman and degrading treatment (Art. 7); Prohibition of medical or scientific experimentation without consent (Art. 7); Prohibition of slavery, slave trade and servitude (Art. 8); Prohibition of imprisonment because of inability to fulfil contractual obligation (Art. 11); Principle of legality in criminal law i.e. the requirement that criminal liability and punishment is limited to clear and precise provisions in the law, that was in force at the time the act or omission took place, except in cases where a later law imposes a lighter penalty (Art. 15); Recognition everywhere as a person before the law (Art. 16); Freedom of thought, conscience and religion (Art. 18). Nonderogable rights dirumuskan dalam Pasal 28I ayat (1) UUD 1945 yang menyatakan sebagai berikut: "Hak untuk hidup, hak untuk tidak disiksa, hak kemerdekaan pikiran dan hati nurani, hak beragama, hak untuk tidak diperbudak, hak untuk diakui sebagai pribadi di hadapan hukum, dan hak untuk tidak dituntut atas dasar hukum yang berlaku surut adalah hak asasi manusia yang tidak dapat dikurangi dalam keadaan apa pun".

$8 \quad$ Andrey Sujatmoko, Op.Cit. 69. 
oleh keluarga korban. Hal ini karena menyangkut masalah perampasan hak hidup manusia, di mana orang-orang PKI itu dibunuh tanpa proses pengadilan. Langkah-langkah penyelesaian pelanggaran berat HAM masa lalu adalah perwujudan dari nilai-nilai kemanusiaan dan keadilan yang terkandung dalam Pancasila yang harus dijunjung tinggi oleh semua pihak termasuk negara. Nilai-nilai kemanusiaan dan keadilan merupakan salah satu elemen penting dari demokrasi sebagaimana diatur dalam UUD 1945. Tanpa adanya penyikapan tegas oleh negara, upaya penyelesaian pelanggaran berat HAM tahun 1965 akan menjadi sia-sia dan yang terjadi adalah berlangsungnya pelanggaran HAM yang terusmenerus seperti munculnya stigma dan diskriminasi dalam berbagai aspek kehidupan para korban. Di samping itu penyelesaian pelanggaran berat HAM tahun 1965 atau extrajudicial killings 1965 adalah upaya menjunjung tinggi kemanusiaan dan keadilan sebagaimana dimaksudkan oleh Pasal 28H Ayat (2) UUD 1945 yaitu: "Setiap orang berhak mendapatkan kemudahan dan perlakuan khusus untuk memperoleh kesempatan dan manfaat yang sama guna mencapai persamaan dan keadilan."
Oleh karena itu, upaya penyelesaian pelanggaran berat HAM masa lalu adalah memberi kewajiban dan tanggung jawab kepada negara untuk menghormati,melindungi, menegakkan dan memajukan HAM seperti yang ditekankan oleh Pasal 71 UU No. 39 Tahun 1999 tentang HAM. Kewajiban dan tanggung jawab negara terjadi karena negara merupakan pengemban kewajiban hukum untuk menyelenggarakan langkah-langkah penyelesaian atas pelanggaran-pelanggaran HAM masa lalu. ${ }^{9}$

Secara umum, sudah jelas bahwa siapa yang harus bertanggung jawab terhadap pelanggaran Hak Asasi Manusia dalam hal ini adalah negara. Disini merujuk pada posisi dan peran negara sebagai state actor, yaitu yang menjalankan semua sendi kehidupan bernegara sebagaimana amanat Undang-Undang Dasar. Disamping itu kewajiban negara tersebut juga lahir dari instrumen-instrumen internasional hak asasi manusia.

Pelanggaran negara terhadap kewajibannya itu dapat dilakukan baik dengan perbuatannya sendiri (acts of commision) maupun oleh karena kelalaiannya sendiri (acts of ommission). ${ }^{10}$ Kewenangan negara untuk bertanggungjawab tentu didasarkan pada negara sebagai subyek hukum inter-

$9 \quad$ Koalisi untuk Keadilan dan Pengungkapan Kebenaran (KKPK), ‘Jalan Indonesia menuju Penyelesaian atas Pelanggaran HAM masa lalu demi Masa Depan Bangsa: Kerangka Dasar untuk Kerja Bersama berlandaskan Konstitusi' (18 Agustus 2015) <http://kkpk.org/wp-content/uploads/2016/01/ Satya-Pilar.pdf> Diakses 12 Maret 2016.

10 Knut D. Asplund, Suparman Marzuki, Eko Riyadi eds., Hukum Hak Asasi Manusia (PUSHAM UII 2008).

11 R.C. Hingorani, Modern International Law (Oceana Publications 1984) 241. 
nasional sekaligus sebagai subyek hak asasi manusia. Negara sebagai aktor atau pemangku kewajiban untuk bertanggungjawab melindungi, menegakkan, dan memajukan hak asasi manusia, bagi warga negaranya, sebagaimana kontrak sosial dan politik negara dengan rakyatnya.

Tanggung jawab negara menurut Hingorani ${ }^{11}$ muncul sebagai akibat dari adanya prinsip persamaan dan kedaulatan negara (equality and sovereignty of state) yang terdapat dalam hukum internasional. Dan jika merujuka pada Dictionary of Law ${ }^{12}$, dianggap sebagai "Obligation of a state to make reparation arising from a failure to comply with a legal obligation under international law."

Berkenaan dengan pertanggungjawaban negara, Shaw melihat ciri-ciri penting tentang pertanggungjawaban yang kemudian disebut sebagai faktor dasar, yaitu: adanya kewajiban hukum internasional yang masih berlaku di antara kedua negara yang bersangkutan; telah terjadi suatu perbuatan atau kelalaian yang melanggar kewajiban itu dan mewajibkan negara tersebut bertanggung jawab; dan perbuatan melanggar hukum atau kelalaian tersebut menimbulkan kehilangan atau kerugian. ${ }^{13}$ Tidak jauh berbeda dari Shaw, Arechaga, juga melihat adanya kesepakatan doktrinal pada proposisi bahwa ada dua unsur penting untuk melahirkan tanggung jawab negara secara internasional, yaitu: pelanggaran suatu kewajiban hukum internasional dan atribusi pelanggaran itu untuk negara sebagai badan hukum. ${ }^{14}$

Pendapat Shaw serta Arechaga dapat memberikan kejelasan tentang bagaimana negara dapat bertanggung jawab terhadap pelanggaran HAM masa lalu, meskipun tindakan itu dilakukan bukan oleh negara secara langsung. Konsisten dengan itu maka kasus extrajudicial killings 1965 dapat dilimpahkan tanggung jawabnya kepada negara. Hal ini sejalan dengan Pasal 4 Responsibility of States for Internationally Wrongful Acts 2001 yang meliputi:

1. The conduct of any State organ shall be considered an act of that State under international law, whether the organ exercises legislative, executive, judicial or any other functions, whatever position it holds in the organization of the State, and whatever its character as an organ of the central Government or of a territorial unit of the State.

2. An organ includes any person or entity which has that status in accordance with the internal law of the State.

Organ negara yang dimaksud Pasal 4 mencakup semua individu atau entitas kolektif yang membentuk organisasi negara, lembaga atau pejabat-pejabat negara yang berdasarkan undangundang memiliki kewenangan untuk bertindak atas nama negara. Ini juga

\footnotetext{
Elizabeth A. Martin ed., A Dictionary of Law (Oxford University Press 2002) 477. Malcolm Shaw, Hukum Internasional (Nusa Media 2013) 774.

14 E.J. de Arechaga \& A. Tanzi, 'State Responsibility' dalam Mohammed Bedjaoui (ed.), International Law: Achievements and Prospects (Martinus Nijhoff Publisher 1991) 348.
} 
termasuk organ badan pemerintah teritorial dalam negara atas dasar yang sama seperti organ pemerintah pusat. ${ }^{15}$ Lebih lanjut menurut Oentoeng Wahyoe, dalam konteks pertanggungjawaban negara terhadap pelanggaran kejahatan internasional juga didasarkan pada vicarious responsibility of State. ${ }^{16}$ Masih menurut Wahjoe, negara dapat dipertanggungjawabkan jika memang ada keterlibatan negara yang meliputi: kebijakan negara (product of State favoring policy), kehendak negara (favored by State conduct) atau oleh negara (product of State action).

Oleh karena itu, sebagai bentuk tanggung jawab negara terhadap kejahatan kemanusiaan, maka perlu mekanisme penyelesaian extrajudicial killings 1965, baik itu melalui mekanisme yudisial maupun mekanisme nonyudisial. Pada prinsipnya kedua mekanisme penyelesaian tersebut memiliki payung hukum yang kuat di mana peran negara menjadi dominan sebagai pihak yang bertanggung jawab.

\section{Penyelesaian melalui Mekanisme Yudisial}

Terkait dengan penyelesaian kasuskasus pelanggaran berat HAM di masa lalu, Penjelasan Umum UU No 26 Tahun 2000 memberikan penegasan sebagai berikut: "Bahwa pelanggaran hak asasi manusia yang berat merupakan extraordinary crimes, maka perlu penyelesaian dengan cara-cara extraordinary, sehingga dapat mewujudkan supremasi hukum untuk mencapai kedamaian, ketertiban, ketentraman, keadilan dan kesejahteraan." Konsisten dengan itu, untuk mendapatkan kepastian hukum yang adil atas peristiwa extrajudicial killings 1965, Pasal 28D ayat (1) UUD 1945 memberikan ketentuan bahwa setiap orang berhak atas pengakuan, jaminan, perlindungan, dan kepastian hukum yang adil serta perlakuan yang sama di hadapan hukum.

Berkaitan dengan penegakan HAM, landasan yuridis yang relevan adalah Pasal 90 ayat (1) UU No. 39 tahun 1999 yang menentukan: "Setiap orang dan sekelompok orang yang memiliki alasan kuat bahwa hak asasinya telah dilanggar dapat mengajukan laporan dan pengaduan lisan atau tertulis pada Komnas HAM." Oleh karena itu proses penyelesaian pelanggaran berat HAM masa lalu seperti extra judicial killings 1965 dapat dilakukan dengan mekanisme yudisial melalui Pengadilan HAM ad hoc atau, dalam perspektif Hukum Internasional, melalui Hybrid Tribunal.

Mekanisme penyelesaian extrajudicial killings 1965 menurut hukum nasional Indonesia dengan melalui Pengadilan HAM ad hoc didasarkan pada UU No. 26 Tahun 2000. UndangUndang ini sebetulnya merupakan adopsi dari Statuta Roma 1998, meski

15 United Nations Legislative Series, Materials On the Responsibility of States for Internationally Wrongful Acts (United Nations 2012) 31.

16 Oentoeng Wahjoe, Hukum Pidana Internasional: Perkembangan Tindak Pidana International \& Proses Penegakannya (Erlangga 2011) 100. 
ada beberapa hal yang kurang, seperti elements of crimes yang tidak ada dalam UU No. 26 Tahun 2000. Ini sangat penting untuk menyamakan pandangan di kalangan penegak hukum dalam proses penyelesaian pelanggaran HAM. Terlepas politik hukum di balik pembuatan UU No. 26 tahun 2000, tetapi semangat untuk menyelesaikan pelanggaran HAM masa lalu setidaknya telah diakomodir dalam Undang-Undang ini. Mekanisme Pengadilan HAM ad hoc berdasarkan UU No. 26 tahun 2000 pernah digunakan untuk mengadili pelanggaran berat HAM di Tim-Tim pasca jajak pendapat. Di samping itu pengadilan nasional merupakan primary forum untuk mengadili para pelanggar HAM berat dengan alasan: (1) keterkaitan dengan masyarakat setempat, sehingga memiliki efek deterrent; (2) memudahkan mencari bukti-bukti, saksi-saksi dan para pelaku; (3) tidak mahal dan lebih mudah dilaksanakan. ${ }^{17}$

Konstruksi penyelesaian extra judicial killings 1965 dengan UU No. 26 Tahun 2000 didasarkan pada Pasal 4, yaitu: "Pengadilan HAM bertugas dan berwenang memeriksa dan memutuskan perkara pelanggaran hak asasi manusia yang berat." Landasan yuridis spesifik untuk pembentukan Pengadilan HAM ad hoc diatur dalam Pasal 43 ayat (1) UU No. 26 Tahun 2000 yang menentukan: "Pelanggaran hak asasi manusia yang berat yang terjadi sebelum diundangkannya Undang-Undang ini, diperiksa dan diputus oleh Pengadilan HAM ad hoc."

Dalam kaitan dengan Pengadilan HAM menurut UU No. 26 Tahun 2000, maka pertanyaanya adalah apakah extra judicial killings 1965 termasuk dalam Pasal 7 UU No. 26 Tahun 2000? Pasal 7 UU No. 26 Tahun 2000 yang meletakkan dasar yurisdiksi material Pengadilan HAM menentukan bahwa perkara yang dapat diadili oleh Pengadilan HAM adalah kejahatan genosida dan kejahatan terhadap kemanusiaan. Sebelum menjawab pertanyaan itu, terlebih dahulu perlu dilihat pada Pasal 9 UU No. 26 Tahun 2000 yang menentukan:

Kejahatan terhadap kemanusiaan sebagaimana dimaksud dalam Pasal 7 huruf $b$ adalah salah satu perbuatan yang dilakukan sebagai bagian dari serangan yang meluas atau sistematik yang diketahuinya bahwa serangan tersebut ditujukan secara langsung terhadap penduduk sipil, berupa: a) Pembunuhan; b) Pemusnahan; c) Perbudakan; d) Pengusiran atau pemindahan penduduk secara paksa; e) Perampasan kemerdekaan atau perampasan kebebasan fisik lain secara sewenangwenang yang melanggar (asas-asas) ketentuan pokok hukum internasional; f) Penyiksaan; g) Perkosaan, perbudakan seksual, pelacuran secara paksa, pemaksaan kehamilan, pemandulan atau sterilisasi secara paksa atau bentukbentuk kekerasan seksual lain yang setara; h) Penganiayaan terhadap suatu kelompok tertentu atau perkumpulan yang didasari persamaan paham politik, ras, kebangsaan, etnis, budaya, agama, jenis kelamin atau alasan lain yang telah diakui secara universal

$17 \quad$ Muladi, Mekanisme Domestik untuk Mengadili Pelanggaran HAM Berat melalui Sistem Pengadilan atas dasar UU No. 26 Tahun 2000 (Elsam 2015) 7. 
sebagai hal yang dilarang menurut hukum internasional; i) Penghilangan orang secara paksa; j) Kejahatan apartheid.

Apakah extrajudicial killings 1965 termasuk dalam cakupan Pasal 9 di atas? Untuk menjawab itu perlu dipahami lebih dahulu the elements of crimes dari kejahatan terhadap kemanusian yang meliputi unsur subjektif dan unsur objektif. Artinya apakah extrajudicial killings 1965 dapat memenuhi unsur subjektif (criminal responsibility/mens rea) dan unsur objektif (criminal act/actus reus). Unsur subjektif mencakup: kesalahan; kemampuan bertanggung jawab; kesengajaan atau kealpaan; dan tidak adanya alasan pemaaf. Unsur objektif mencakup: perbuatan itu memenuhi Undang-Undang; bersifat melawan hukum; dan tidak adanya alasan pembenar.

Supaya extrajudial killings untuk dapat digolongkan sebagai kejahatan terhadap kemanusiaan menurut Pasal 7 huruf b UU No. 26 Tahun 2000, setidaknya harus memenuhi unsurunsur sebagai berikut:

(1)Unsur material yang fokusnya pada perbuatan (conduct), akibat (consequences) dan keadaan-keadaan (circumstances) yang menyertai perbuatan;

(2) Unsur mental yang relevan yang fokusnya tertuju pada bentuk kesengajaan (intent), pengetahuan (knowledge), atau keduanya.
Pasal 9 UU No. 26 Tahun 2000 menentukan bahwa kejahatan terhadap kemanusiaan sebagaimana dimaksud dalam Pasal 7 huruf b UU No. 26 Tahun 2000 harus mencerminkan dua elemen. Pertama, perbuatan yang dilakukan sebagai bagian dari serangan yang meluas (widespread) dan sistematik (systematic) yang diketahuinya bahwa serangan tersebut ditujukan pada penduduk sipil. Kedua, keharusan adanya pengetahuan (with knowledge) pelaku bahwa perbuatan yang dilakukan merupakan bagian dari atau dimaksudkan untuk menjadi bagian serangan yang meluas atau sistematik terhadap penduduk sipil. ${ }^{18}$

Pasal 9 UU No. 26 tahun 2000 tidak memberikan batasan bahwa harus lebih dari satu tindak pidana serangan yang meluas dan sistematik yang ditujukan secara langsung terhadap penduduk sipil (pembunuhan, perkosaan, penyiksaan, dll). Hal ini berarti, salah satu dari tindak pidana tersebut terpenuhi sudah cukup dinyatakan sebagai tindak pidana kejahatan terhadap kemanusiaan.

Penyelesaian kasus-kasus pelanggaran berat HAM menurut hukum internasional melalui pengadilan internasional memiliki urgensi karena berkaitan dengan kejahatan internasional atau kejahatan di bawah yurisdiksi hukum internasional seperti genosida, kejahatan terhadap kemanusiaan dan kejahatan perang. Dalam perspektif hukum internasional, alasan bahwa kejahatan internasional harus dibentuk melalui pengadilan 
internasional adalah: kejahatan tersebut melanggar norma internsional yang bersifat jus cogens atau peremptory norm; terhadap pelaku kejahatan tidak boleh bebas tanpa hukuman (impunity); kejahatan HAM berat tidak mengenal daluarsa (non-statutory limitation).

Proses penegakan hukum dalam konteks internasional Secara teori dibagi menjadi dua, yaitu: Direct Enforcement System (Penegakan Hukum Secara Langsung) dan Indirect Enforcement System (Penegakan Hukum Secara Tidak Langsung). Direct Enforcement System merupakan penegakan hukum pidana internasional oleh mahkamah pidana internasional, seperti: Nuremberg, International Military Tribunal for the Far East (Tokyo), International Criminal Tribunal for the Former Yugoslavia(ICTY), International Criminal Tribunal for Rwanda (ICTR), dan International Criminal Court (ICC). Sedangkan penegakan hukum pidana internasional secara Indirect Enforcement System adalah penegakan hukum pidana internasional melalui hukum pidana nasional di masing-masing negara, tempat kejahatan tersebut terjadi. Seperti hybrid tribunal di Timor Leste, Serra Leone, Kamboja.

Dalam konteks penyelesaian extrajudicial killings 1965, penyelesaian melalui hybrid tribunals menurut Andrey Sujatmoko, dikarenakan adanya faktor-faktor unwillingness dan inability dari negara pelaku pelang- garan berat HAM yang dapat menyebabkan mekanisme internasional mengambil alih fungsi pengadilan nasional. ${ }^{19}$ Selain itu, ada juga faktor lain seperti aturan yang berimplikasi menghambat penyelesaian pelanggaran HAM, seperti Pasal 43 ayat (2) UU No. 26 tahun 2000 di mana Pengadilan HAM ad hoc sebagaimana dimaksud dibentuk atas usul Dewan Perwakilan Rakyat Republik Indonesia berdasarkan peristiwa tertentu dengan Keputusan Presiden. Tentu saja UndangUndang ini design to fail karena didasari nalar politis yang kuat atau mengandung politik hukum yang menghambat penyelesaian pelanggaran HAM.

Pada kondisi deadlock baik karena undang-undang maupun karena situasi politik, atau beberapa negara yang mengalami nasib seperti itu (unwillingness dan inability) melakukan penyelesaian melalui mekanisme hybrid tribunals seperti Sierra Leone dengan Special Court of Sierra Leone dan Timor Leste dengan Special Panels for Serious Crimes. Hybrid tribunal disebut dengan pengadilan campuran, karena terdiri dari unsur-unsur yang bersifat campuran, seperti menyangkut kebangsaan orang-orang yang bekerja (hakim, jaksa, panitera) terdiri dari warga negara setempat maupun orang asing yang diangkat oleh PBB. Demikian pula dengan hukum yang digunakan adalah kombinasi antara hukum nasional setempat dengan hukum internasional. ${ }^{20}$

\footnotetext{
19 Andrey Sujatmoko, Tanggungjawab Negara atas Pelanggaran HAM Indonesia, Timor Leste dan lainnya (PT. Grasindo 2005) 179.

20 Ibid.
} 
Pengadilan campuran atau hybrid tribunals merupakan penemuan baru dalam bidang hukum pidana internasional yang disebut dengan "generasi ketiga" dari perkembangan pidana internasional. Perkembangan ini merupakan terobosan baru dalam penegakan hukum pidana HAM internasional di mana model ini dikelompokkan dari beberapa campuran negara-negara dan komponen internasional yang menawarkan pendekatan yang tertuju pada keadilan internasional secara keseluruhan pada satu sisi dan keadilan dalam negeri di sisi lain. Pengadilan hybrid menurut PBB adalah: "courts of mixed composition and jurisdiction, encompassing both national and international aspects, usually operating within the jurisdiction where the crimes occurred." 11

Hybrid tribunals merupakan kombinasi internasional dan lokal, yang dalam perspektif Higonnet, adalah produk dari berbagi akuntabilitas peradilan antara negara-negara di mana mereka berfungsi dan juga PBB: "Blending the international and the local, existing hybrids are products of judicial accountability sharing between the states in which they fucntion and the United Nations." ${ }^{2}$ Ini mungkin salah satu model penegakan hukum progresif, yang menurut Suparman Marzuki, karena menawarkan bentuk pemikiran dan penegakan hukum yang tidak submisif terhadap sistem yang ada, tetapi afirmatif. Afirmatif berarti keberanian untuk melakukan pembebasan dari praktik konvensional dan menegaskan penggunaan satu cara yang lain, yang menerobos pakem-pakem praktik hukum yang telah lama berlangsung. ${ }^{23}$

Oleh karena itu, pilihan hybrid tribunals memiliki kekuatan-kekuatan internasional yang memiliki daya tekan dan kredibilitas dalam penyelenggaran peradilan HAM masa lalu. Namun, apapun dalil-dalil pembentukan hybrid tribunlas, paling tidak memiliki perspektif yang sama tentang tujuan terbentuknya pengadilan yang dapat mewujudkan perdamaian dan keadilan bagi para korban.

\section{Mekanisme Non-yudisial}

Seringkali penyelesaian nonyudisial atau di luar peradilan kasus pelanggaran HAM masa lalu menjadi pilihan karena dinilai lebih memuaskan pihak-pihak yang sedang berkonflik. Namun demikian, kadang penyelesaian di luar peradilan memunculkan polemik karena dianggap menyimpangi peradilan pidana, khususnya dalam perspektif positivisme hukum.

Gagasan proses penyelesaian di luar peradilan pidana ini juga dikenal dengan istilah restorative justice atau

${ }_{21}$ United Nations, Rule of Law Tools for Post Conflict States: Maximizing the Legacy of Hybrid Courts (United Nations 2008) 1.

22 Ethel Higonnet, 'Restructuring Hybrid Courts: Local Empowerment and National Criminal Justice Reform' (Yale Law School Legal Scholarship Repository: Student Scholarship Papers 2005) <http:// digitalcommons.law.yale.edu/student_papers> Diakses 12 Maret 2016. 
keadilan restoratif. Konsep keadilan restoratif adalah sebuah pendekatan untuk keadilan yang tertuju pada kebutuhan para korban dan pelaku, serta masyarakat yang terlibat. Pada dasarnya keadilan restoratif melihat proses pemidanaan dari perspektif yang berbeda, yaitu pemenuhan atas kerugian yang diderita korban. Meminjam perspektif $\mathrm{PBB}$, keadilan restoratif didasarkan pada beberapa asumsi yang mendasari, yaitu: respons terhadap kejahatan harus memperbaiki sebanyak mungkin kerugian yang diderita oleh korban; pelanggar harus dibawa untuk memahami bahwa perilaku mereka tidak dapat diterima dan bahwa itu memiliki beberapa konsekuensi nyata bagi korban dan masyarakat; pelaku dapat dan harus menerima tanggung jawab atas tindakan mereka; korban harus memiliki kesempatan untuk mengekspresikan kebutuhan mereka dan berpartisipasi dalam menentukan cara terbaik bagi pelaku untuk memberikan reparasi; dan masyarakat memiliki tanggung jawab untuk berkontribusi pada proses ini. ${ }^{24}$ Ada dua mekanisme non-yudisial dalam rangka penyelesaian pelanggaran berat HAM masa lalu yang akan didiskusikan di sini sebagai solusi untuk extrajudicial killings 1965, yaitu Komisi Kebenaran dan Rekonsiliasi (KKR) serta Komisi Islah.
Pendekatan rekonsiliasi, meski dianggap tidak menjamin terwujudnya rasa keadilan, telah diterapkan oleh lebih dari 20 negara untuk menyelesaikan pelanggaran berat HAM masa lalu. Negara-negara itu antara lain: Afrika Selatan (1995), Chili (1990-1992), El Savador (1992-1994) serta Meksiko (1992). Di Indonesia, Komisi Kebenaran dan Rekonsiliasi merupakan alternatif pilihan setelah mekanisme yudisial melalui pengadilan HAM ad hoc berdasarkan UU No. 26 Tahun 2000 menghadapi kesulitan prosedural. Menurut Jusuf Kalla, upaya ini meniru metode penyelesaian kasus pelanggaran berat HAM di Afrika Selatan dengan slogan "to forgive not to forget." Kalla lebih lanjut mengatakan metode penyelesaian di Afrika Selatan semacam islah di Indonesia. ${ }^{25}$

Ada yang berpandangan bahwa Komisi Kebenaran dan Rekonsiliasi merupakan fenomena transisi yang muncul dari konteks negara-negara yang sedang menghadapi transisi dari rejim otoriter ke rezim demokratis. ${ }^{26}$ Instittute for Democracy and Electoral Asistance (IDEA) menjelaskan pentingnya komisi kebenaran dan rekonsiliasi dengan alasan sebagai berikut: "Reconciliation is an overarching process which includes the search for justice, forgiveness, healing and so on. At its simplest, it means finding a way to live

\footnotetext{
$24 \quad$ United Nations, Handbook On Restorative Justice Programes (United Nations Publication 2006$) 8$.

25 Kontras, 'Pembatalan UU KKR oleh Mahkamah Konstitusi' (Berita KontraS No. 06/XI-XII/2006) <https://www.kontras.org/buletin/indo/2006-11-12.pdf> Diakses 12 Maret 2016.

26 Ifdhal Kasim, 'Apakah Komisi Kebenaran dan Rekonsiliasi itu?' (2000) 1 Briefing Paper Series tentang Komisi Kebenaran dan Rekonsiliasi-Elsam 1, 1.
} 
alongside former enemies - not necessarily to love them, or forget the past in any way, but to coexist with them, to develop the degree of cooperation necessary to share our society with them, so that we all have better lives together than we have had separately." 27 Sejalan dengan itu, menurut Erasmus Ndemole, komisi kebenaran adalah: "bodies set up to investigate a past history of violations of human rights in a particular country which can include violations by the military or other government forces or armed opposition forces." 28

Dalam praktiknya, kinerja dari komisi kebenaran dan rekonsiliasi nampak dalam contoh kasus E1 Salvador yang dikemukakan oleh Priscilla B. Hayner. ${ }^{29}$ El Salvador membentuk Komisi Kebenaran sebagai bagian dari kesepakatan damai antara pemerintah dan oposisi bersenjata. Komisi diberikan waktu delapan bulan untuk menulis laporan yang menguraikan luasnya pelanggaran HAM dan pelanggaran hukum kemanusiaan internasional setelah lebih dari dua belas tahun perang saudara di El Salvador. Staf Komisi mendengarkan kesaksian dari saksi atau korban kekerasan, menyelidiki sejumlah kasus secara mendalam, dan dikompilasi secara statistik pada puluhan ribu kasus dibawa untuk menjadi perhatiannya.

Di Indonesia, dasar hukum pembentukan KKR adalah UU No. 27 tahun 2004. Akan tetapi Undang-Undang tersebut dibatalkan melalui putusan Mahkamah Konstitusi. Sebagai implikasi putusan tersebut kelembagaan KKR di Indonesia menjadi non-eksis dan hingga kini belum ada payung hukum pengganti sebagai dasar hukum untuk penyelesaian pelanggaran berat HAM di masa lalu melalui KKR.

Alternatif lain untuk penyelesaian extrajudicial killings 1965 melalui mekanisme non-yudisial dapat dilakukan dengan menggunakan cara kultural. Mekanisme kultural yang dibangun atas nilai-nilai serta normanorma lokal akan dapat membangun keseimbangan, perdamaian serta integrasi sosial pasca konflik. Mekanisme ini berbeda dengan penyelesaian menggunakan hukum atau kekuasaan, yang menurut Saldi Ernas cenderung menafikan kemungkinan adanya nilai-nilai tertentu yang mampu mendorong masyarakat untuk mengelola perbedaan dengan cara-cara yang tepat, sehingga melahirkan integrasi dan perdamaian yang otentik dalam masyarakat. ${ }^{30}$

$27 \quad$ David Bloomfield, Teresa Barnes, Luc Huyse eds., Reconciliation After Violent Conflict: A Handbook (International Institute for Democracy and Electoral Assistance 2003) 12.

28 Erasmus Ndemole Migyikra, Truth and Reconciliation Commissions: A Comparative Study of South Africa, Ghana and Sierra Leone' (Thesis Master of Arts, European University Centre for Peace Studies 2008) 16.

29 Priscilla B. Hayner, 'Fifteen Truth Commissions 1974 to 1994: A Comparative Study' (1994) 16 Human Rights Quarterly 597, 599.

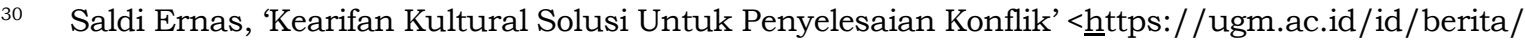
9396-kearifan.kultural.solusi.untuk.penyelesaian.konflik> Diakses, 12 Juli 2016. 
Islah adalah suatu pendekatan kultural yang persuasif serta memiliki landasan filosofis dan teologis bagi sebagian besar masyarakat Indonesia yang beragama Islam. Islah menurut A. Yani Wahid merupakan warisan religius untuk resolusi konflik dalam tragedi kemanusiaan. Islah masih menurut Wahid adalah memiliki landasan filosofis dan teologis yang mengarah kepada pemulihan harkat dan martabat semua pihak yang terlibat, mengganti suasana konflik dengan perdamaian (asas silaturahmi), menghapus hujat menghujat dengan pemaafan, menghentikan tuntut menuntut dan salah menyalahkan (asas saling memaafkan dan memohon ampunan dari Tuhan). ${ }^{31}$

Islah juga merupakan pilihan yang sifatnya voluntaristik, suka rela dan tanpa paksaan. Kedua belah pihak, baik korban maupun pelaku, samasama dalam posisi tidak saling menekan dan memilih secara bebas jalan menuju islah. ${ }^{32}$ Begitu juga ruang lingkup islah yang cukup luas, yaitu mencakup aspek-aspek segi kehidupan manusia baik pribadi maupun sosial. Oleh karena itu islah adalah proses mendamaikan pihak-pihak yang bertikai dengan menghilangkan segala bentuk pertikaian dan permusuhan atau dendam yang berkepanjangan yang dapat merugikan semua pihak.
Menurut Mahrus dan Syarif Hidayat, istilah islah memiliki akar kata dari bahasa Arab yaitu sholuhayang berarti bagus, baik; ashlaha yang berarti memperbaiki. Sholluha diartikan sebagai membaikan atau menyelesaikan; shoolaha berarti berdamai, as sulhu berarti perdamaian, as sholaahiyah berarti kepantasan; as sholihu berarti yang bagus, baik, ishlahun berarti perbaikan, koreksi. ${ }^{33}$ Masih menurut Mahrus dan Syarif Hidayat, islah merupakan satu konsep utuh dalam penyelesaian suatu perkara. Secara mendasar prinsip-prinsip yang harus ada dalam proses islah adalah: pengungkapan kebenaran; adanya pihak yang meliputi pihak yang berkonflik yang dalam hal kejahatan harus ada korban dan pelaku, sedangkan pihak yang lain adalah mediator; merupakan proses sukarela tanpa paksaan; dan keseimbangan dan kewajiban.

Sedangkan islah dan beragam derivasinya menurut Wahyudi Akmaliyah secara garis besar memiliki kecenderungan pada tiga makna dalam alQur'an, antara lain: lebih mengarah pada upaya memperbaiki sesuatu, mendamaikan, menghilangkan sengketa maupun kerusakan, berusaha menciptakan perdamaian, membawa keharmonisan, serta menganjurkan orang untuk berdamai satu dengan

\footnotetext{
$31 \quad$ A. Yani Wahid, 'Islah, Resolusi Konflik untuk Rekonsiliasi' (Kompas, 16 Maret 2001).

32. Binsar Gultom, Pelanggaran HAM dalam Hukum Keadaan Darurat di Indonesia. (Gramedia Pustaka Utama 2010) 248.

33 Mahrus Ali \& Syarif Nurhidayat, Penyelesaian Pelanggaran HAM Berat in Court System \& Out Court System (Gratama Publishing 2011) 283.
} 
yang lainnya; reformasi, baik secara individu maupun kelompok agar menjadi lebih baik; upaya menjaga ekologi dan kepedulian terhadap anak yatim. ${ }^{34}$

Dari pandangan Wahyudi, islah yang dimaksud dalam upaya penyelesaian extrajudicial killings 1965 adalah konsep yang pertama yaitu untuk perdamaian serta meluruhkan kebencian di antara pelaku maupun korban. Lebih lanjut Wahyudi mengungkapkan esensi islah menurut Islam yang memiliki efek positif bagi orang-orang yang bertikai, yaitu adanya pengakuan kesalahan dan saling memaafkan antara keduanya. Prosesi islah kemudian akan menjadi pertanda bahwa perselisihan yang selama ini ada akan dianggap selesai, hal ini untuk mengeliminir timbulnya dendam di antara pelaku dan korban. Tak heran jika islah dianggap sebagai perbuatan yang terpuji dalam kaitannya dengan perilaku manusia.

\section{PENUTUP}

Negara memiliki kewajiban untuk menjaga dan melindungi HAM warga negaranya. Jika negara gagal memenuhi kewajibannya tersebut, baik yang dilakukan dengan perbuatannya sendiri (acts of commision) maupun oleh karena kelalaiannya (acts of ommission), maka negara telah melakukan pelanggaran HAM dan, sebagai implikasinya, negara harus bertang- gung jawab. Oleh karena itu, sebagai bentuk tanggung jawabnya, negara harus melakukan penyelesaian terhadap extrajudicial killings 1965 yang merupakan pelanggaran berat HAM, di mana tidak berlaku daluarsa, baik melalui mekanisme yudisial maupun mekanisme non-yudisial.

\section{DAFTAR BACAAN}

\section{Buku}

Adam, Asvi Marwan, Melawan Lupa: Menepis Stigma setelah Prahara 1965 (PT. Kompas Media Nusantara 2015).

Ali, Mahrus, \& Syarif Nurhidayat, Penyelesaian Pelanggaran HAM Berat In Court System \& Out Court System (Gratama Publishing 2011).

Arechaga, E.J. de \& A. Tanzi, 'State Responsibility' dalam Mohammed Bedjaoui ed., International Law: Achievements and Prospects (Martinus Nijhoff Publisher 1991).

Asplund, Knut D., Suparman Marzuki, Eko Riyadi, eds., Hukum Hak Asasi Manusia (PUSHAM UII 2008).

Bloomfield, David, Teresa Barnes, Luc Huyse eds., Reconciliation After Violent Conflict: A Handbook (International Institute for Democracy and Electoral Assistance 2003).

Gultom, Binsar, Pelanggaran HAM dalam Hukum Keadaan Darurat di Indonesia. (Gramedia Pustaka Utama 2010).

\footnotetext{
$34 \quad$ Wahyudi Akmaliah, 'Islah sebagai Dalih: Studi Kasus Penyelesaian Konflik Peristiwa Tanjung Priok (1984) dan Talang Sari (1989) Pasca Rezim Orde Baru' (2014) 16 Jurnal Masyarakat \& Budaya $167,170-171$
} 
Hingorani, R.C., Modern International Law (Oceana Publications 1984).

Kurnia, Titon Slamet, Reparasi (Reparation) terhadap Korban Pelanggaran HAM di Indonesia (PT. Citra Aditya Bakti 2005).

Martin, Elizabeth A., ed., A Dictionary of Law (Oxford University Press 2002).

Marzuki, Suparman, Pengadilan HAM diIndonesia: Melanggengkan Impunity (Erlangga 2012).

Muladi, Mekanisme Domestik untuk Mengadili Pelanggaran HAM Berat melalui Sistem Pengadilan atas dasar UU No. 26 Tahun 2000 (Elsam 2015).

Rosa, John, Dalih Pembunuhan Massal: Kudeta 30 September dan Kudeta Suharto (Institut Sejarah Sosial Indonesia dan Hasta Mitra 2008).

Shaw, Malcolm, Hukum Internasional (Nusa Media 2013).

Sujatmoko, Andrey, Tanggungjawab Negara atas Pelanggaran HAM Indonesia, Timor Leste dan lainnya (PT. Grasindo 2005) 179.

, Hukum HAM dan Hukum Humaniter (Rajawali Press 2015).

Sulistyo, Hermawan, Palu Arit di Ladang Tebu: Sejarah Pembantaian Massal yang Terlupakan (Jombang-Kediri 1965-1966) (Kepustakaan Populer Gramedia 2011).

United Nations Legislative Series, Materials On the Responsibility of States for Internationally Wrongful Acts (United Nations 2012).
United Nations, Handbook On Restorative Justice Programes (United Nations Publication 2006) 8. , Rule of Law Tools for Post Conflict States: Maximizing the Legacy of Hybrid Courts (United Nations 2008).

Wardaya, Baskara T., ed., Luka Bangsa Luka Kita; Pelanggaran Ham Masa Lalu dan Tawaran Rekonsiliasi (Galang Press 2014).

Wahjoe, Oentoeng, Hukum Pidana Internasional: Perkembangan Tindak Pidana International \& Proses Penegakannya (Erlangga 2011).

\section{Jurnal}

Akmaliah, Wahyudi, 'Islah sebagai Dalih: Studi Kasus Penyelesaian Konflik Peristiwa Tanjung Priok (1984) dan Talang Sari (1989) Pasca Rezim Orde Baru' (2014) 16 Jurnal Masyarakat \& Budaya.

Hayner, Priscilla B., 'Fifteen Truth Commissions 1974 to 1994: A Comparative Study' (1994) 16 Human Rights Quarterly.

Higonnet, Ethel, 'Restructuring Hybrid Courts: Local Empowerment and National Criminal Justice Reform' (Yale Law School Legal Scholarship Repository: Student Scholarship Papers 2005) <http://digitalcommons. law.yale.edu/student_ papers> Diakses 12 Maret 2016.

Kasim, Ifdhal, 'Apakah Komisi Kebenaran dan Rekonsiliasi itu?' (2000) 1 Briefing Paper Series tentang 
Komisi Kebenaran dan Rekonsiliasi-Elsam.

\section{Lain-lain}

Migyikra, Erasmus Ndemole, Truth and Reconciliation Commissions: A Comparative Study of South Africa, Ghana and Sierra Leone' (Thesis Master of Arts, European University Centre for Peace Studies 2008). 